\title{
Character Association Studies for Yield and Quality Traits in Chilli
}

\author{
G. Kranthi Rekha ${ }^{\text {* }}$, C. Venkata Ramana ${ }^{2}$, L. Naram Naidu ${ }^{2}$, K. Umajyothi ${ }^{3}$, \\ M. Paratpararao ${ }^{4}$ and K. Sasikala ${ }^{5}$
}

${ }^{1}$ Department of Vegetable science, COH, Dr. Y.S.R.H.U., V.R.Gudem-534101, India

(Part of Ph.D (Hort), thesis submitted by the first author to Dr. Y.S.R. Horticultural University, V.R.Gudem)

${ }^{2}$ HRS, Lam Farm, Guntur, Dr. YSR Horticultural University -522034, India

${ }^{3}$ Department of Vegetable science, COH, Dr. Y.S.R.H.U., V.R.Gudem-534101, India

${ }^{4}$ Department of Genetics \& Plant Breeding, COH, Dr. Y.S.R.H.U., V.R.Gudem-534101, India

${ }^{5}$ Department of Agronomy, COH, Dr. Y.S.R.H.U., V.R.Gudem-534101, India

*Corresponding author

\section{A B S T R A C T}

The present investigation was carried out at Horticultural Research Station,

Keywords

Chilli, Quality traits, Correlation and Path analysis

Article Info

Accepted:

07 July 2019

Available Online:

10 August 2019
Lam, Guntur, Andhra Pradesh to elucidate the interrelationship among six quality traits and fruit yield and to estimate the direct and indirect effects of quality traits on yield in forty three genotypes of chilli comprising $30 \mathrm{~F} 1$ hybrids, 11 parents and two commercial checks. Fruit yield per plant has showed positive significant association with oleoresin, pungency and red carotenoids whereas, its association with yellow carotenoids was negative and significant. The path analysis revealed that the quality parameters viz., ascorbic acid, oleoresin, pungency and red carotenoids had positive direct effect on fruit yield per plant. Among these four, only red carotenoids have recorded high positive direct effect indicated that direct selection for fruit yield per plant through this trait will be effective.

\section{Introduction}

Chilli (Capsicum annuum L) is an important crop both as a vegetable and as a spice and it is extensively cultivated in India and is marketed as a whole fruit, green and dry, powder, paste and oleoresin. The quality of red chilli is based on colour, pungency and wrinkling nature of the fruit. The quality parameters can be improved through proper breeding programmes. The knowledge of the inheritance and the genetics of economic traits are essential if selection for the simultaneous improvement of these traits is to be most effective. In most of the chilli growing nations, the research is concentrated on improving yield, quality and their inter relationships to achieve the required degree of 
success in selection and breeding programmes. An attempt was therefore made to analyze the degree of association between yield and quality parameters so as to suggest a basis for selection in chilli improvement.

\section{Materials and Methods}

The experiment was carried out at Horticultural Research Station, Lam with 43 chilli genotypes. The trial was laid out in a randomized block design with three replications. Seedlings were transplanted at a spacing of $75 \times 30 \mathrm{~cm}$. The crop received timely management practices as per recommended package of practices. All the recommended cultural practices were followed to raise good chilli crop. Ten randomly selected plants in each experimental plot were used for recording observations on Vitamin $\mathrm{C}$ content, Oleoresin (\%), pungency (\%), total colour, red carotenoids, yellow carotenoids and dry fruit yield per plant (g). The crop was maintained properly till last harvest and observations on growth, yield as well as yield contributing characters was noted on five randomly selected plants in each plot at different stages of the crop.

Ascorbic acid content of mature green fruits was estimated by volumetric method described by Sadasivam and Balasubramanian (1987). The oleoresin content was estimated as per the procedure given by Ranganna (1986). The capsaicin content of fruits was estimated by colorimetric method described by Balasubramanian et al., (1982). The oleoresin content was estimated as per the procedure given by Ranganna (1986).

Total extractable color of fruits measured in ASTA (American Spice Trade Association) units was determined using the procedure outlined by ASTA (1986). All the carotenoid pigments present in hot pepper have chromophore properties that allow their grouping in two isochromic families i.e. red (R) and yellow (Y). The $\mathrm{R}$ fraction contains pigments capsanthin, capsorubin and capsanthin-5, 6-epoxide, whereas $\mathrm{Y}$ fraction contains remaining pigments such as zeaxanthin, violaxanthin, antheraxanthin, $\beta$ cryptoxanthin, $\quad \beta$-carotene $\quad$ and cucurbitaxanthin A, which act as precursors of the former (Minguez and Perez, 1998). Yellow and red fractions were determined using UVvisible spectrophotometric measurements at two characteristic wavelengths and application of Lambert-Beer law for multi-component mixtures according to procedure developed by Hornero-Mendez and Minguez-Mosquera, 2001.

The phenotypic correlation coefficient and genotypic correlation coefficient and direct and indirect effects were computed by using procedure given by Dewey and Lu (1959).

\section{Results and Discussion}

The estimates of phenotypic and genotypic correlation coefficient (Table 1 and 2) revealed that the genotypic correlations were higher than the corresponding phenotypic correlations for most of the characters indicating high heritability of the traits under study as suggested by earlier reports of Farhad et al., (2008), Kumar et al., (2012) and Janaki et al., (2018).

The characters viz., Oleoresin, pungency and red carotenoids were positively correlated with fruit yield per plant whereas, the rest of the characters were negatively associated with fruit yield per plant. The character yellow carotenoids were significantly and negatively correlated with fruit yield per plant at both phenotypic and genotypic levels. These findings suggested that selection for fruit yield per plant based on oleoresin, pungency and red carotenoids is beneficial for further crop improvement programme. These results are in 
consonance with earlier reports of Gupta et al., (2009), Sharma et al., (2010) and Janaki et al., 2018 for pungency. Pungency had significant and negative association with vitamin $\mathrm{C}$ at both phenotypic and genotypic levels indicating a significant increase in capsaicin content leads to decrease in vitamin $\mathrm{C}$ and vice-versa. The inter relationship among total colour value, red and yellow carotenoids were significant and positive indicating that simultaneous selection of these traits is possible and also suggested that total colour value increases significantly with increase in red and yellow. These findings are supported by the earlier observations of Naresh et al., (2013) and Janaki et al., (2018).
The results of path analysis studies (Table 3 and 4; Fig. 1) revealed that ascorbic acid, oleoresin, pungency and red carotenoids at both phenotypic and genotypic levels had positive direct effect on fruit yield per plant indicating that direct selection based on these traits may be helpful in evolving high yielding varieties of chilli. These findings are in agreement with earlier reports of Kumar et al., (2012) and Janaki et al., (2018) for vitamin C, pungency and red carotenoids. The total colour value and yellow carotenoids had negative direct effect on fruit yield per plant. Janaki et al., (2018) who had also reported the negative direct effect of total colour value on fruit yield in chilli.

\begin{tabular}{|c|c|c|c|c|c|c|c|}
\hline \multicolumn{8}{|c|}{ Table.1 Genotypic correlation coefficiencts for six quality traits in chilli (Capsicum annuum $\mathbf{L}$.) } \\
\hline Character & $\begin{array}{l}\text { Vitamin } \\
\mathrm{C}\end{array}$ & $\begin{array}{c}\text { Oleoresin } \\
(\%)\end{array}$ & $\begin{array}{c}\text { Pungency } \\
(\%)\end{array}$ & $\begin{array}{l}\text { Total } \\
\text { Colour }\end{array}$ & $\begin{array}{c}\text { Red } \\
\text { Carotinoids }\end{array}$ & $\begin{array}{c}\text { Yellow } \\
\text { Carotinoids }\end{array}$ & $\begin{array}{l}\text { Dry Fruit } \\
\text { Yield/ } \\
\text { Plant (g) }\end{array}$ \\
\hline Vitamin $\mathbf{C}$ & & -0.1327 & $-0.3175^{* *}$ & 0.047 & $-0.1947 *$ & 0.1604 & -0.0822 \\
\hline $\begin{array}{l}\text { Oleoresin } \\
(\%)\end{array}$ & & & $0.2873 * *$ & -0.0625 & -0.027 & -0.0297 & 0.1994* \\
\hline $\begin{array}{l}\text { Pungency } \\
\text { (\%) }\end{array}$ & & & & -0.0443 & -0.0748 & -0.141 & $0.1785^{*}$ \\
\hline Total Colour & & & & & $0.8143 * *$ & $0.8468 * *$ & -0.0444 \\
\hline $\begin{array}{l}\text { Red } \\
\text { Carotinoids }\end{array}$ & & & & & & $0.5518 * *$ & 0.1776* \\
\hline $\begin{array}{l}\text { Yellow } \\
\text { Carotinoids }\end{array}$ & & & & & & & $-0.2147^{*}$ \\
\hline
\end{tabular}

\begin{tabular}{|c|c|c|c|c|c|r|r|}
\hline \multicolumn{6}{|c|}{ Table.2 Phenotypic correlation coefficiencts for six quality traits in chilli (Capsicum annuum L.) } \\
\hline Character & $\begin{array}{c}\text { Vitamin } \\
\text { C }\end{array}$ & $\begin{array}{c}\text { Oleoresin } \\
(\%)\end{array}$ & $\begin{array}{c}\text { Pungency } \\
(\%)\end{array}$ & $\begin{array}{c}\text { Total } \\
\text { Colour }\end{array}$ & $\begin{array}{c}\text { Red } \\
\text { Carotinoids }\end{array}$ & $\begin{array}{c}\text { Yellow } \\
\text { Carotinoids }\end{array}$ & $\begin{array}{c}\text { Dry } \\
\text { Fruit } \\
\text { Yield/ } \\
\text { Plant (g) }\end{array}$ \\
\hline Vitamin C & & -0.0778 & $-0.2962^{* *}$ & 0.0185 & -0.1478 & 0.1084 & $\mathbf{- 0 . 0 8 8 1}$ \\
\hline $\begin{array}{c}\text { Oleoresin (\%) } \\
\text { Pungency (\%) }\end{array}$ & & $0.2559^{* *}$ & -0.0669 & -0.0247 & -0.0848 & $\mathbf{0 . 1 2 6 8}$ \\
\hline Total Colour & & & -0.0273 & -0.0484 & -0.1187 & $\mathbf{0 . 1 3 5 1}$ \\
\hline $\begin{array}{c}\text { Red } \\
\text { Carotinoids }\end{array}$ & & & & $0.7398^{* *}$ & $0.723 * *$ & $\mathbf{- 0 . 0 4 4 6}$ \\
\hline $\begin{array}{c}\text { Yellow } \\
\text { Carotinoids }\end{array}$ & & & & & $0.4334^{* *}$ & $\mathbf{0 . 1 1 4 1}$ \\
\hline
\end{tabular}




\begin{tabular}{|c|c|c|c|c|c|c|c|}
\hline \multicolumn{8}{|c|}{ Table.3 Genotypic path coeffcients for six traits in chilli } \\
\hline Character & $\begin{array}{l}\text { Vitamin } \\
\text { C }\end{array}$ & $\begin{array}{c}\text { Oleoresin } \\
(\%)\end{array}$ & $\begin{array}{c}\text { Pungenc } \\
\text { y }(\%)\end{array}$ & $\begin{array}{c}\text { Total } \\
\text { Colour }\end{array}$ & $\begin{array}{c}\text { Red } \\
\text { Carotinoids }\end{array}$ & $\begin{array}{c}\text { Yellow } \\
\text { Carotinoids }\end{array}$ & $\begin{array}{l}\text { Dry Fruit Yield/ } \\
\text { Plant (g) }\end{array}$ \\
\hline Vitamin C & 0.1863 & -0.0247 & -0.0591 & 0.0088 & -0.0363 & 0.0299 & -0.0822 \\
\hline Oleoresin $(\%)$ & -0.0218 & 0.164 & 0.0471 & -0.0103 & -0.0044 & -0.0049 & 0.1994* \\
\hline Pungency (\%) & -0.0563 & 0.051 & 0.1775 & -0.0079 & -0.0133 & -0.025 & $0.1785 *$ \\
\hline Total Colour & -0.012 & 0.0159 & 0.0113 & -0.2543 & -0.207 & -0.2153 & -0.0444 \\
\hline $\begin{array}{l}\text { Red } \\
\text { Carotinoids }\end{array}$ & -0.1227 & -0.017 & -0.0471 & 0.5131 & 0.6302 & 0.3477 & 0.1776* \\
\hline $\begin{array}{l}\text { Yellow } \\
\text { Carotinoids }\end{array}$ & -0.0557 & 0.0103 & 0.049 & -0.294 & -0.1916 & -0.3471 & $-0.2147 *$ \\
\hline
\end{tabular}

\begin{tabular}{|l|c|c|c|c|r|r|r|}
\hline \multicolumn{1}{|c|}{ Table.4 Phenotypic path coeffcients for six traits in chilli } \\
\hline & $\begin{array}{c}\text { Vitamin } \\
\text { Character }\end{array}$ & $\begin{array}{c}\text { Oleoresin } \\
(\mathbf{\%})\end{array}$ & $\begin{array}{c}\text { Pungency } \\
(\mathbf{\%})\end{array}$ & $\begin{array}{c}\text { Total } \\
\text { Colour }\end{array}$ & $\begin{array}{c}\text { Red } \\
\text { Carotinoids }\end{array}$ & $\begin{array}{c}\text { Yellow } \\
\text { Carotinoids }\end{array}$ & $\begin{array}{l}\text { Dry Fruit } \\
\text { Yield/ Plant (g) }\end{array}$ \\
\hline Vitamin C & $\mathbf{0 . 0 1 6 2}$ & -0.0013 & -0.0048 & 0.0003 & -0.0024 & 0.0018 & $\mathbf{- 0 . 0 8 8 1}$ \\
\hline Oleoresin (\%) & -0.0065 & $\mathbf{0 . 0 8 4 2}$ & 0.0215 & -0.0056 & -0.0021 & -0.0071 & $\mathbf{0 . 1 2 6 8}$ \\
\hline Pungency (\%) & -0.0311 & 0.0268 & $\mathbf{0 . 1 0 4 9}$ & -0.0029 & -0.0051 & -0.0125 & $\mathbf{0 . 1 3 5 1}$ \\
\hline Total Colour & -0.0018 & 0.0066 & 0.0027 & $-\mathbf{- 0 . 0 9 8 4}$ & -0.0728 & -0.0711 & $\mathbf{- 0 . 0 4 4 6}$ \\
\hline $\begin{array}{l}\text { Red } \\
\text { Carotinoids }\end{array}$ & -0.0423 & -0.0071 & -0.0139 & 0.2117 & $\mathbf{0 . 2 8 6 2}$ & 0.1241 & $\mathbf{0 . 1 1 4 1}$ \\
\hline $\begin{array}{l}\text { Yellow } \\
\text { Carotinoids }\end{array}$ & -0.0225 & 0.0176 & 0.0246 & -0.1498 & -0.0898 & $\mathbf{- 0 . 2 0 7 2}$ & $\mathbf{- 0 . 1 7 2 1 *}$ \\
\hline
\end{tabular}

Fig.1 Genotypic path diagram for dry fruit yield per plant

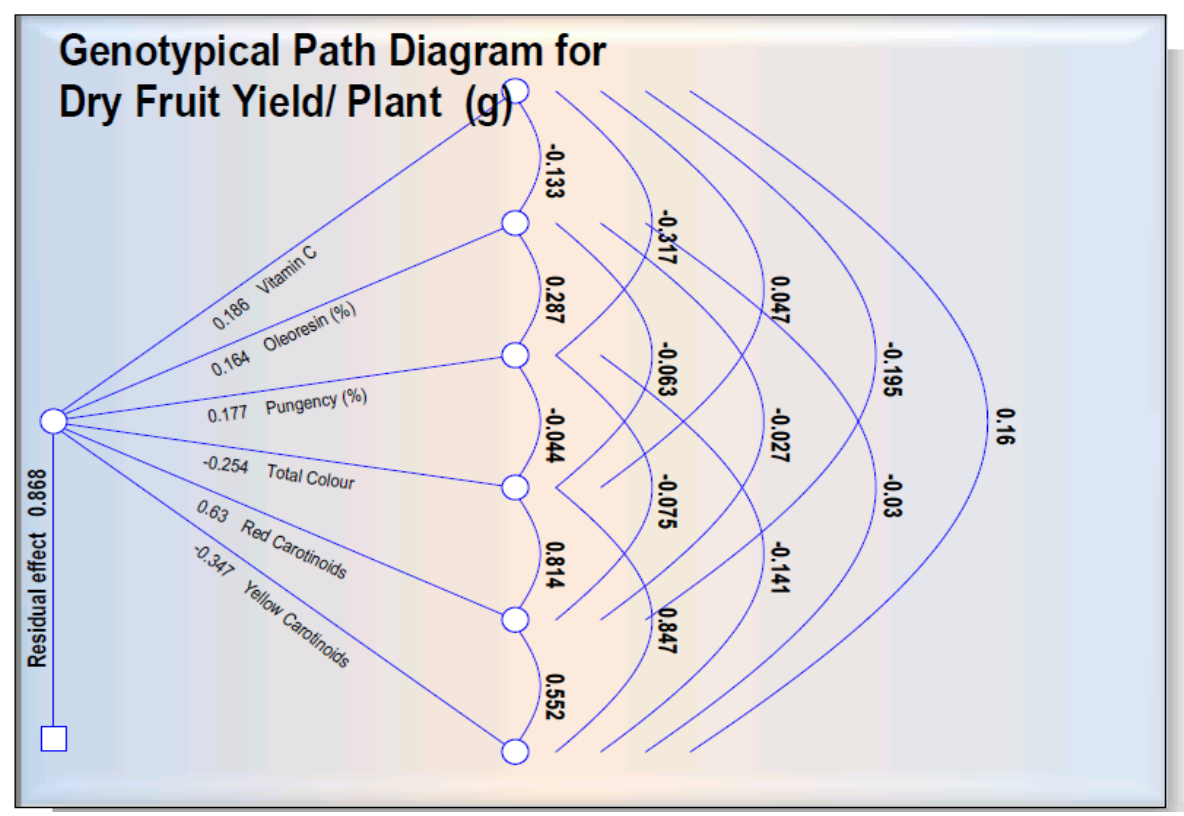


Lenka and Mishra (1973) have suggested scales for path coefficients with values 0.00 to 0.09 as negligible, 0.10 to 0.19 low, 0.20 to 0.29 moderate, 0.30 to 0.99 high and more than 1.00 as very high path coefficients. Accordingly, red carotenoids had high positive direct effect whereas, yellow carotenoids had moderate negative direct effect on fruit yield at genotypic level. Red carotenoids at phenotypic level had moderate positive direct effect while yellow carotenids had moderate negative direct effect on fruit yield. The traits Vitamin $\mathrm{C}$, oleoresin and pungency at genotypic level had low direct effect on yield per plant whereas vitamin C and oleoresin had negligible direct effect on yield at phenotypic level. Bijalwan and Mishra (2016) also reported low positive direct effect for ascorbic acid. Janaki et al., (2018) also observed high positive direct effect for red carotenoids.

The red carotenoids indirectly influence the fruit yield through total colour value and yellow carotenoids whereas, the vitamin $\mathrm{C}$ content indirectly influence the fruit yield via total colour value, yellow carotenoids. The trait pungency indirectly influence the fruit yield through oleoresin.

The results of correlation studies suggest that fruit yield per plant can be improved by selecting hybrids for oleoresin, pungency and red carotenoids as they have recorded positive significant association with fruit yield per plant. As per path analysis, emphasis must be given to the characters like ascorbic acid, oleoresin, pungency and red carotenoids in selection programme for yield improvement as they have observed positive direct effects.

Thus in the present study correlation and path analysis collectively revealed the importance of ascorbic acid, oleoresin, pungency and red carotenoids in determining selection criteria for improvement of dry fruit yield per plant.

\section{References}

ASTA. 1986. Official analytical methods of the American spice trade association. $2^{\text {nd }}$ edition, ASTA, Englewood Chiffs, N.I.

Balasubramanian, T., Raj, D., Kasthuri, R. and Rangaswami, P. 1982. Indian Journal of Horticulture. 39: 239.

Bijalwan, P. and Mishra, A.C. 2016. Correlation and Path Coefficient Analysis in Chilli (Capsicum annuum L.) for Yield and Yield Attributing Traits. International Journal of Science and Research. 5(3): 1589-1592

Dewey D.R. and Lu K.H. 1959. A correlation and path analysis of components of crested wheat grass seed production. Agronomy Journal. 51: 515-518

Farhad, M., Hasanuzzaman, M., Biswas, B.K., Azad, A.K. and Arifuzzaman, M. 2008. Reliability of yield contributing characters for improving yield potential in chilli (Capsicum annum). Intl. $J$. Sustain. Crop. Prod. 3: 30-38.

Gupta, A.M., Singh, D. and Kumar, A. 2009. Genetic variability, genetic advance and correlation in chilli (Capsicum annuum). Indian. J. Agri. Sci. 79(3): 221-223.

Hornero-Mendez, D. and Minguez-Mosquera, I.M. 2001. Rapid spectrophotometric determination of red and yellow isochromic carotenoid fractions in paprika and red pepper oleoresins. $J$. Agri. Fd. Chem. 49: 3584-3588.

Hornero-Mendez, D. and Minguez-Mosquera, I.M. 2001. Rapid spectrophotometric determination of red and yellow isochromic carotenoid fractions in paprika and red pepper oleoresins. Journal of Agricultural Food Chemistry. 49: 3584-3588.

Janaki, M., Naram Naidu L., Venkata Ramana, C., Dilip Babu, Koteswara 
Rao, K and Uma Krishna, K. 2018. Correlation and path analysis studies among biochemical traits and yield in chilli (Capsicum annuum L.) genotypes. Electronic Journal of Plant Breeding, 9: 1563-1569.

Kumar, D., Bahadur, V., Rangare, S.B. and Singh, D. 2012. Genetic variability, heritability and correlation studies in chilli (Capsicum annuum L.). Hort. Flora Res. Spectrum. 1: 248-252.

Lenka, D. and Mishra, B. 1973. Path coefficient analysis of yield in rice varieties. Indian J. Agric. Sci. 43: 376379.

Minguez-Mosquera, M.I. and Perez-Galvez, A. 1998. A colour quality in paprika oleoresins. Journal of Agricultural
Food Chemistry. 46: 5124-5127.

Naresh, P., Madhavi, R.K., Shivashankara, K.S. and Christopher, G.M. 2013. Genotypic variation for biochemical compounds in capsicum. Indian J. Hort. 70: 43-47.

Ranganna, S. 1986. Handbook of analysis and quality control for fruits and vegetable products. 2nd edition. p: 259.

Sadasivam, S. and Balasubramanian, T. 1987. Practical manual in Biochemistry. TNAU, Coimbatore, p: 14.

Sharma, V.K., Semwal, C.S., Uniyal, S.P. 2010. Genetic variability and character association analysis in bell pepper (Capsicum annuum L.). J. Hort. Forest. 2: 058-065.

\section{How to cite this article:}

Kranthi Rekha, G., C. Venkata Ramana, L. Naram Naidu, K. Umajyothi, M. Paratpararao and Sasikala, K. 2019. Character Association Studies for Yield and Quality Traits in Chilli. Int.J.Curr.Microbiol.App.Sci. 8(08): 569-574. doi: https://doi.org/10.20546/ijcmas.2019.808.068 